\title{
Sulfuration Resistance of Five Experimental Ag-Pd-Au-Cu Alloys with Low Pd Content of 10 or $12 \%$
}

\author{
Setsuo SAITOH, Yoshima ARAKI and Masayuki TAIRA \\ Department of Dental Materials Science and Technology, Iwate Medical University School of Dentistry, 1-3-27, Chuo-dori, \\ Morioka, Iwate 020-8505, Japan \\ Corresponding author, Setsuo Saitoh E-mail:setsuos@iwate-med.ac.jp
}

Received June 22, 2005/Accepted March 2, 2006

\begin{abstract}
Commercial Ag-based alloy (46Ag-20Pd-12Au-20Cu alloy) is widely used in Japan as a casting alloy. As opposed to the commercial composition, we prepared five experimental Ag-based alloys with reduced Pd content of 10 or $12 \%$, increased Au content of 20 to $30 \%$, and reduced $\mathrm{Cu}$ content of 12 to $20 \%$. We then evaluated their sulfuration resistance by analyzing cast specimen surfaces dipped in $0.1 \% \mathrm{Na}_{2} \mathrm{~S}$ solution with SEM/EPMA, TF-XRD, and XPS. It became evident that all alloys were susceptible to sulfuration in the segregated Ag-rich Pd-poor phases. The degree and speed of sulfuration, however, differed among the six alloys examined. In particular, one experimental alloy (46Ag-10Pd-30 Au- $12 \mathrm{Cu}$ ) possessed a sulfuration resistance equal or superior to that of commercial Ag-based alloy, while the other four experimental alloys were inferior in sulfuration resistance. Based on the results of this study, we concluded that our newly developed $46 \mathrm{Ag}-10 \mathrm{Pd}-30 \mathrm{Au}-12 \mathrm{Cu}$ alloy could be employed as a new sulfuration-resistant Ag-based casting alloy - which is especially useful if the price of Pd is skyrocketing again.
\end{abstract}

Key words: Ag-Pd-Au-Cu alloys, Low Pd content, Sulfuration resistance

\section{INTRODUCTION}

Ag-Pd-Au-Cu alloys with many different compositions (basically, Ag-based alloys) have been developed in Japan ${ }^{1-3)}$. With due consideration to the factors of price, strength, and sulfuration resistance, Ag$20 \mathrm{Pd}-12 \mathrm{Au}-\mathrm{Cu}$ alloys with varying contents of $\mathrm{Ag}$ (circa 46\%) and $\mathrm{Cu}$ (circa 20\%) are routinely used as cast inlays, crowns and bridges in Japanese dental clinics $^{1,2)}$. However, the major drawback of Ag-based alloys lies in the sulfuration of $\mathrm{Ag}$ matrix $^{4-6)}$. To circumvent this problem, $\mathrm{Pd}$ and $\mathrm{Au}$ are usually $\operatorname{added}^{1,2)}$.

Six years ago, due to the very high price of $\mathrm{Pd}$, there was a strong intent to partially replace $\mathrm{Pd}$ content with $\mathrm{Au}$ content in $\mathrm{Ag}-20 \mathrm{Pd}-\mathrm{Au}-\mathrm{Cu}$ alloys ${ }^{7)}$. To this end, Yoshida et al. and Endo et al. have developed new Ag-Pd-Au-Cu alloys with $\mathrm{Pd}$ contents of $5 \%{ }^{7,8)}$ and $15 \%{ }^{5)}$ respectively - both of which demonstrated adequate strength and sulfuration resistance. To date, no other related systematic studies have since been reported. Although presently, Pd costs lower than $\mathrm{Au}$, there is always a lurking possibility of another price increase because $\mathrm{Pd}$ is produced only in politically unstable countries ${ }^{1,2)}$. Against this background, it is still important to develop new Ag$\mathrm{Pd}-\mathrm{Au}-\mathrm{Cu}$ alloys with less $\mathrm{Pd}$ content $^{1,2)}$.

In our new Ag-Pd-Au-Cu alloy system, we designed five alloy compositions based on the strategy to reduce $\mathrm{Pd}$ content from the standard control of $20 \%$ to a pre-set 10 or $12 \%$ while altering $\mathrm{Ag}$ (between 38 and 46\%), $\mathrm{Cu}$ (between 12 and 20\%), and
$\mathrm{Au}$ (between 20 and $30 \%$ ) contents.

To evaluate the sulfuration resistance of $\mathrm{Ag}$ based alloys, the immersion test in $\mathrm{Na}_{2} \mathrm{~S}$ solution has often been conducted ${ }^{9-13)}$. Sulfurated or corroded surfaces were then analyzed using scanning electron microscopy/electron probe microanalysis (SEM/EPMA $)^{14,15)}$, X-ray diffraction (XRD) ${ }^{16,17)}$, and $\mathrm{X}$-ray photoelectron spectroscopy (XPS) ${ }^{5,18-21)}$.

The aims of this investigation were to: (1) examine metallography by SEM/EDX; and (2) evaluate sulfuration resistance by SEM/EPMA, thin film (TF)-XRD, and XPS of cast one commercial Ag$20 \mathrm{Pd}-12 \mathrm{Au}-\mathrm{Cu}$ alloy (control) and five experimental self-prepared Ag-low $\mathrm{Pd}-(10$ to $12 \%) \mathrm{Au}-\mathrm{Cu}$ alloys.

\section{MATERIALS AND METHODS}

\section{Alloy design}

Table 1 shows the compositions, molar fractions of $\mathrm{Pd}+\mathrm{Au}$, and codes of control commercial Ag-20Pd$12 \mathrm{Au}-\mathrm{Cu}$ alloy and five experimental Ag-low Pd-Au$\mathrm{Cu}$ alloys examined in this study. The sum of molar fraction of $\mathrm{Pd}$ and $\mathrm{Au}$ increased from 0.218 (EX-1) to $0.276(\mathrm{EX}-5)$, while that of PALA was 0.244 . Upon our request, five experimental Ag-based alloy plates (about $5 \times 10 \times 1 \mathrm{~mm}$ ) were manufactured by a commercial company (Nihonbashi Tokuriki Co., Tokyo, Japan).

\section{Specimen preparation by casting}

Six Ag-based alloy specimens (either $6 \times 6 \times 1.5 \mathrm{~mm}$ or $20 \times 20 \times 0.4 \mathrm{~mm}$ ) were prepared by lost wax cast- 
Table 1 Compositions, molar fractions of $\mathrm{Pd}+\mathrm{Au}$, and codes of control and five experimental $\mathrm{Ag}$-low $\mathrm{Pd}-\mathrm{Au}-\mathrm{Cu}$ alloys

\begin{tabular}{|c|c|c|c|c|c|c|c|c|}
\hline & \multicolumn{6}{|c|}{ Composition（wt\%） } & \multirow{2}{*}{$\begin{array}{l}\text { Molar fraction } \\
\text { of } \mathrm{Pd}+\mathrm{Au}\end{array}$} & \multirow{2}{*}{ Code } \\
\hline & $\mathrm{Ag}$ & $\mathrm{Pd}$ & $\mathrm{Au}$ & $\mathrm{Cu}$ & Zn & Others & & \\
\hline Control alloy ${ }^{1}$ & 46 & 20 & 12 & 20 & - & 2 & $0.244^{*}$ & PALA \\
\hline Experimental alloy $1^{2}$ & 46 & 12 & 20 & 20 & 2 & - & 0.218 & $\mathrm{EX}-1$ \\
\hline Experimental alloy $2^{2}$ & 42 & 12 & 24 & 20 & 2 & - & 0.242 & EX-2 \\
\hline Experimental alloy $3^{2}$ & 46 & 12 & 24 & 16 & 2 & - & 0.249 & EX-3 \\
\hline Experimental alloy $4^{2}$ & 38 & 10 & 30 & 20 & 2 & - & 0.261 & $\mathrm{EX}-4$ \\
\hline Experimental alloy $5^{2}$ & 46 & 10 & 30 & 12 & 2 & - & 0.276 & $\mathrm{EX}-5$ \\
\hline
\end{tabular}

${ }^{1}$ Castwell M.C., GC Co., Tokyo, Japan.

${ }^{2}$ Experimental alloys manufactured by Nihonbashi Tokuriki Co., Tokyo, Japan, upon our request.

*Molar fraction of control alloy was calculated assuming that 'Others' component was zinc.

ing in air with cristobalite investment (conventional type, GC, Tokyo, Japan), blowtorch (Uni-blowpipe, Yoshida, Tokyo, Japan), and centrifugal casting machine (Kerr Centrifico Casting Machine, Kerr, Romulus, USA). All cast specimens were benchcooled, taken out, abraded in water with \#1500 SiC waterproof abrasive papers, followed by fine polishing with $0.3-\mu \mathrm{m}$ alumina suspension. They were next washed by ultrasonic agitation in acetone and deionized water for 10 minutes each, and then stored in a desiccator for metallography and immersion tests in $\mathrm{Na}_{2} \mathrm{~S}$ solution.

\section{Metallographic examination of cast specimens}

For SEM/EDX, six Ag-based alloy specimens $(6 \times 6$ $\times 1.5 \mathrm{~mm})$ were dipped in $25 \%\left(\mathrm{NH}_{4}\right)_{2} \mathrm{~S}_{2} \mathrm{O}_{8}$ solution for 10 minutes, ultrasonically cleaned in deionized water for 10 minutes, and then air-dried naturally. Their metallographic observations and semiquantitative elemental analyses were conducted using SEM/EDX (S-4700, Hitachi, Tokyo, Japan/EMAX7000, Horiba Seisakusho, Kyoto, Japan) at an acceleration voltage of $15 \mathrm{kV}$.

Surface analysis after immersion in $0.1 \% \quad \mathrm{Na}_{2} \mathrm{~S}$ solution

For SEM/EPMA, six Ag-based alloy specimens $(6 \times$ $6 \times 1.5 \mathrm{~mm}$ ) were dipped in $15 \mathrm{ml}$ of $0.1 \% \mathrm{Na}_{2} \mathrm{~S}$ solution for one and seven days at $37^{\circ} \mathrm{C}$, followed by ultrasonic cleaning in deionized water for 10 minutes and natural air-dry. They were then analyzed with an SEM/EPMA (JXA-8900L, JEOL, Tokyo, Japan). Area scan $(100 \times 100 \mu \mathrm{m})$ was carried out at an acceleration voltage of $15 \mathrm{kV}$ and a probe current of $6 \times$ $10^{-8}$ A to detect the distribution of six elements ( $\mathrm{S}$, $\mathrm{Ag}, \mathrm{Pd}, \mathrm{Cu}, \mathrm{Zn}$, and $\mathrm{Au}$ ) in each alloy.

For TF-XRD, six Ag-based alloy specimens (20 $\times 20 \times 0.4 \mathrm{~mm}$ ) were dipped in $125 \mathrm{ml}$ of $0.1 \% \mathrm{Na}_{2} \mathrm{~S}$ solution for one and seven days at $37^{\circ} \mathrm{C}$, followed by ultrasonic cleaning in deionized water for 10 minutes and natural air-dry. They and un-dippped specimens were then analyzed by TF-XRD with a diffractometer (JDX-3500, JEOL, Tokyo, Japan) using $\mathrm{Cu} \mathrm{K} \alpha$ radia- tion as the X-ray source. Glancing angle of the specimen ( $\theta$ angle) was fixed at $1^{\circ}$ or $3^{\circ}$ against the incident beam. Characteristic XRD peaks were then labeled with reference to standard powder diffraction data stored in the diffractometer's workstation.

For XPS, six Ag-based alloy specimens $(6 \times 6 \times$ $1.5 \mathrm{~mm}$ ) were dipped in $15 \mathrm{ml}$ of $0.1 \% \mathrm{Na}_{2} \mathrm{~S}$ solution for one day at $37^{\circ} \mathrm{C}$, followed by ultrasonic cleaning in deionized water for 10 minutes and natural airdry. They and un-dipped specimens were then analyzed by XPS in wide and narrow scan modes using an XPS (AXIS-HSi, Kratos, UK) with $\mathrm{Mg} \mathrm{K} \alpha$ radiation operated at $15 \mathrm{kV}$ accelerating voltage and $3 \mathrm{~mA}$ current under a vacuum of $4 \times 10^{-9}$ torr. Analysis area on each alloy was an ellipse approximately 200 $\times 600 \mu \mathrm{m}$ in diameter. Binding energy scale was calibrated by the $\mathrm{C} 1 \mathrm{~s}$ peak at $284.8 \mathrm{eV}$, while seven elements ( $\mathrm{S}, \mathrm{Ag}, \mathrm{Pd}, \mathrm{Au}, \mathrm{Cu}, \mathrm{O}$, and $\mathrm{C}$ ) were identified by XPS peaks of S 2p, Ag 3d, Pd 3d, Au 4f, Cu 2p, $\mathrm{O} 1 \mathrm{~s}$, and $\mathrm{C} 1 \mathrm{~s}$ respectively.

\section{RESULTS}

Metallographic examination of cast specimens Fig. 1 shows the SEM photomicrographs and (grain) phases revealed by EDX of cast control Ag-20Pd$12 \mathrm{Au}-\mathrm{Cu}$ alloy and five experimental Ag-low $\mathrm{Pd}-\mathrm{Au}-$ $\mathrm{Cu}$ alloys. All alloys were heterogeneous in composition. Each alloy had two to four different phases with varied elemental compositions among the individual phases.

In terms of phases, PALA had three phases (A, $\mathrm{B}$, and $\mathrm{C}$ ), EX-1 had four phases (D, E, F, and $\mathrm{G}$ ), EX-2 had three phases (H, I, and J), EX-3 had three phases (K, L, and $\mathrm{M})$, EX-4 had three phases (N, O, and $\mathrm{P}$ ), and EX-5 had two phases ( $\mathrm{Q}$ and $\mathrm{R}$ ). Nonetheless, each alloy had at least two distinctive phases, namely, Ag-rich Pd-poor phase (C in PALA, G in EX$1, \mathrm{~J}$ in $\mathrm{EX}-2, \mathrm{M}$ in $\mathrm{EX}-3, \mathrm{P}$ in $\mathrm{EX}-4$, and $\mathrm{Q}$ in $\mathrm{EX}-5)$ and Ag-poor Pd-rich phase (B in PALA, D and $F$ in $\mathrm{EX}-1, \mathrm{I}$ in $\mathrm{EX}-2, \mathrm{~L}$ in $\mathrm{EX}-3, \mathrm{O}$ in $\mathrm{EX}-4$, and $\mathrm{R}$ in $\mathrm{EX}-$ 5). 

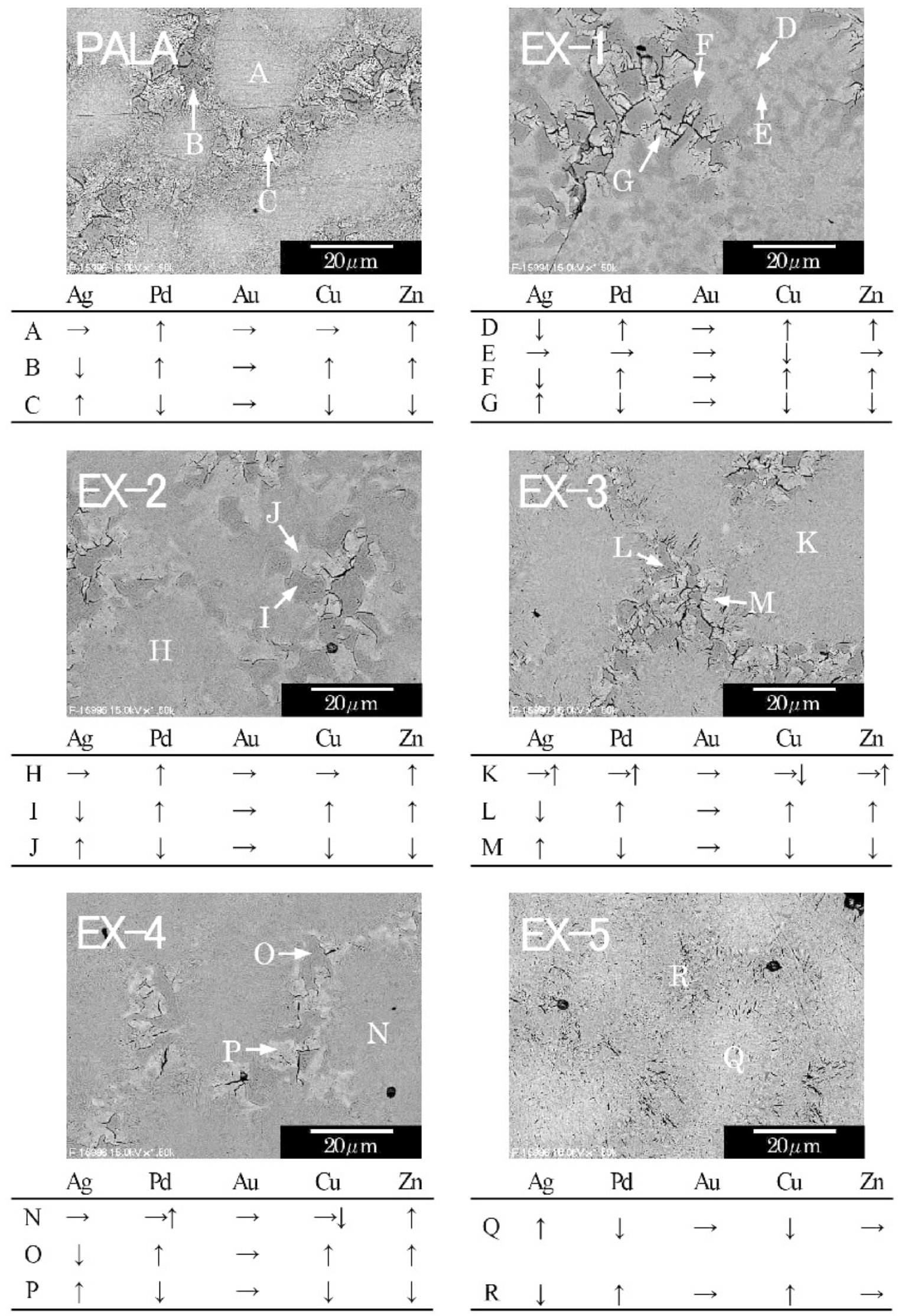

Fig. 1 SEM photographs and phases revealed by EDX of cast control Ag-20Pd-12Au-20Cu alloy and five experimental Ag-low Pd-Au-Cu alloys. 
EPMA analyses after immersion in $0.1 \% \mathrm{Na}_{2} \mathrm{~S}$ solution

Figs. 2 to 8 show the black and white EPMA photomicrographs (composition images $(\mathrm{CP})$, element $\mathrm{S}$, element $\mathrm{Ag}$, element $\mathrm{Pd}$, element $\mathrm{Cu}$, element $\mathrm{Zn}$, and element $\mathrm{Au}$ ) of cast control $\mathrm{Ag}-20 \mathrm{Pd}-12 \mathrm{Au}-\mathrm{Cu}$ alloy and five experimental $\mathrm{Ag}$-low $\mathrm{Pd}-\mathrm{Au}-\mathrm{Cu}$ alloys immersed in $0.1 \% \mathrm{Na}_{2} \mathrm{~S}$ for one day (top) and seven days (bottom), respectively.

On CP in EPMA photomicrographs (Fig. 2), dark and black areas reflect lower atomic weight elements (e.g., S) or voids, while bright and white areas are made up of higher atomic weight elements (e.g., Au). Large black areas formed quickly on EX-1 after one day's immersion and apparently grew after seven days' immersion. Black stains and dots

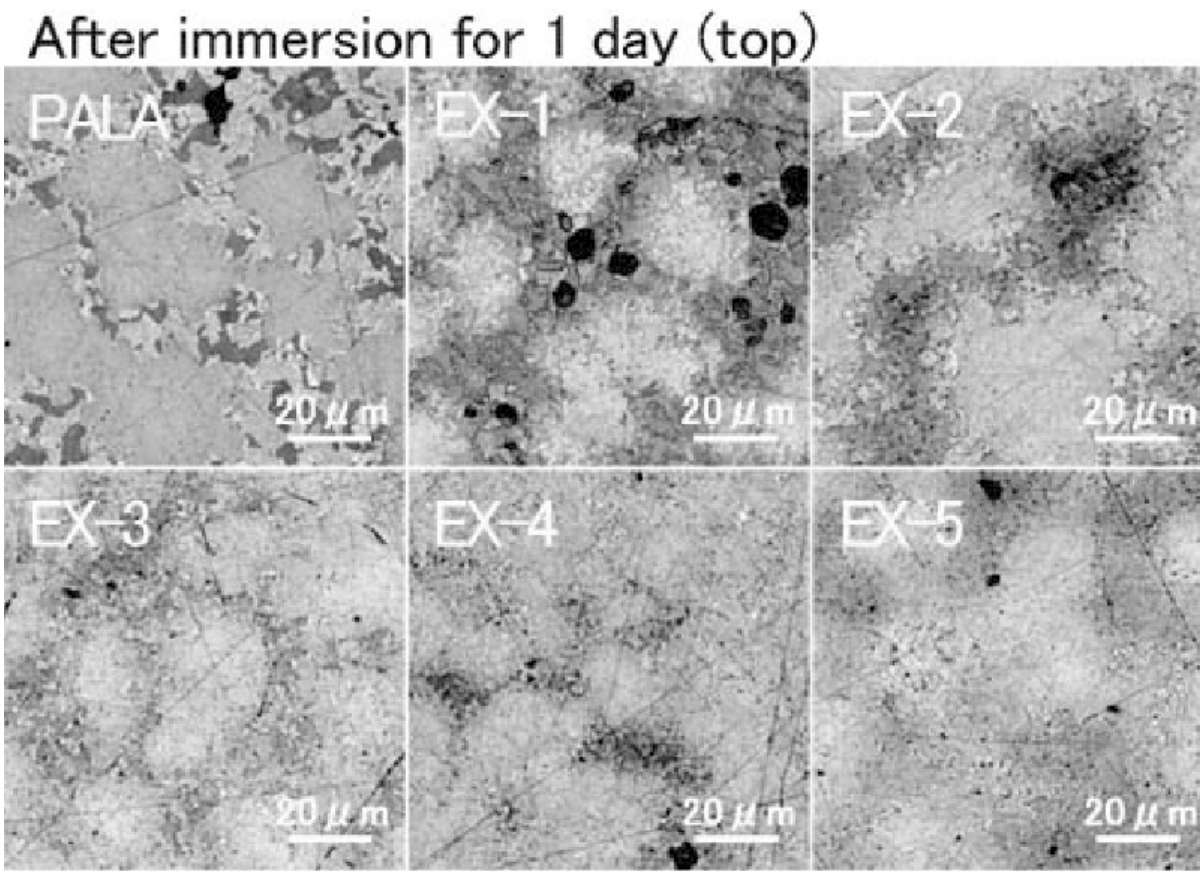

\section{After immersion for 7 days (bottom)}

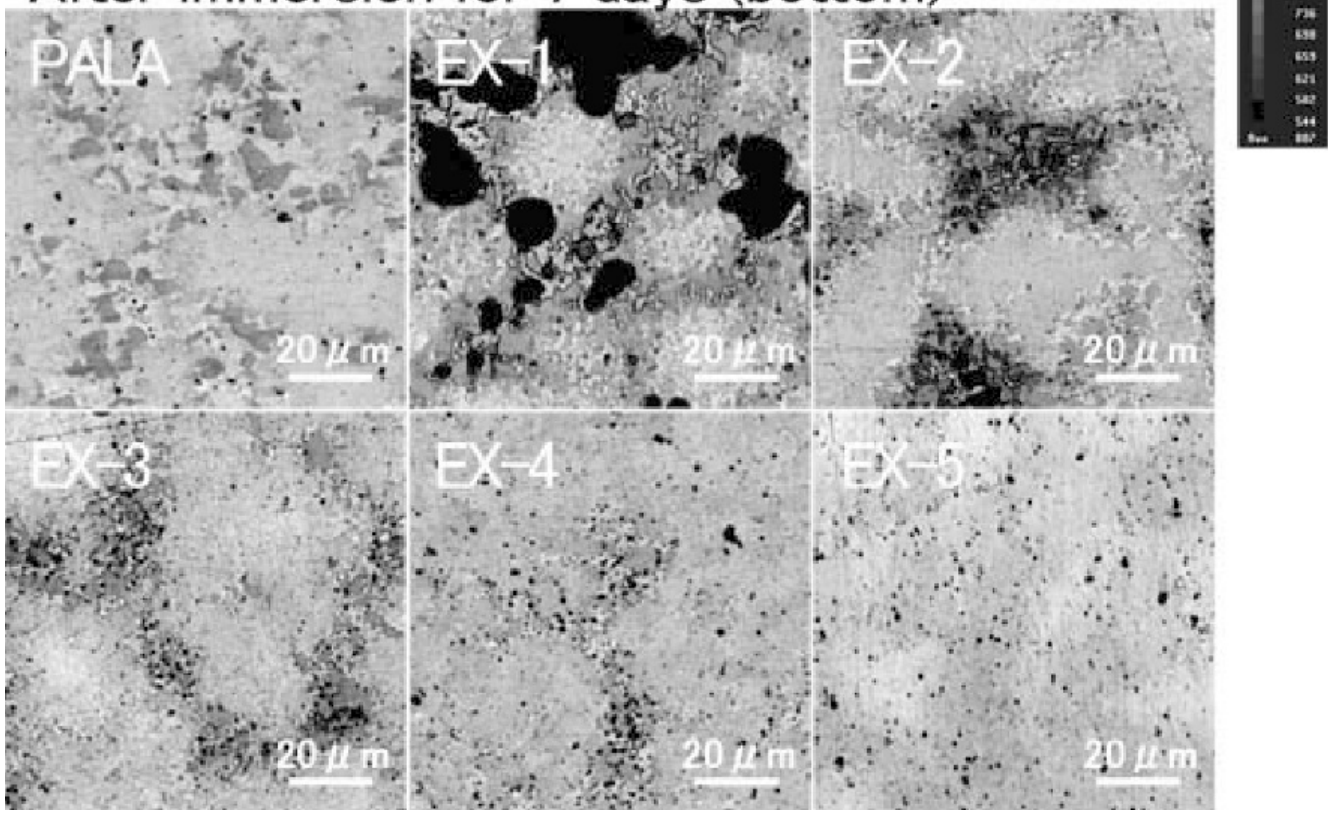

Fig. 2 CP (composition images) in EPMA photomicrographs of cast control Ag-20Pd-12Au-20Cu alloy and five experimental Ag-low $\mathrm{Pd}-\mathrm{Au}-\mathrm{Cu}$ alloys immersed in $0.1 \% \mathrm{Na}_{2} \mathrm{~S}$ for 1 day (top) and 7 days (bottom) 
were also observed on the other five alloys, which tended to increase and enlarge as the immersion period increased from one to seven days.

As for black and white EPMA elemental mappings (Figs. 3-8), if a region contains a larger amount of the element searched, it will appear whiter and brighter.

On element S EPMA photomicrographs (Fig. 3), sulfides formed aggressively on EX-1, EX-2, EX-3, and EX-4 after one day's immersion and grew significantly as the immersion period increased to seven days. Little sulfide was produced on PALA and EX5 after one day's immersion, but precipitated slightly and sparsely after seven days' immersion.

On element Ag EPMA photomicrographs (Fig. 4), considerable segregation of $\mathrm{Ag}$ was noticed for
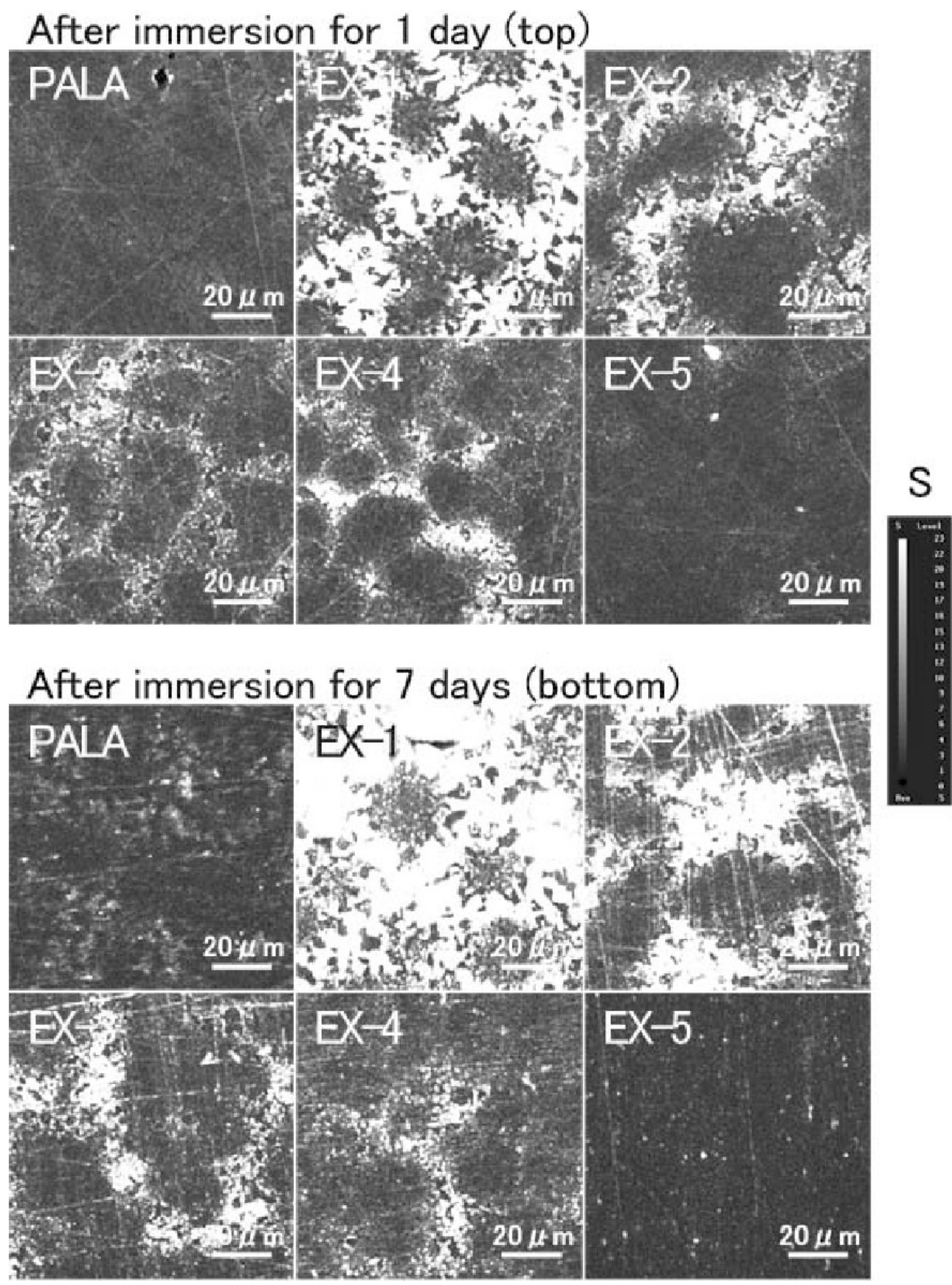

Fig. 3 Element S EPMA photomicrographs of cast control Ag-20Pd-12Au-20Cu alloy and five experimental Ag-low Pd-Au-Cu alloys immersed in $0.1 \% \mathrm{Na}_{2} \mathrm{~S}$ for 1 day (top) and 7 days (bottom). 
PALA, EX-1, EX-2, EX-3, and EX-4, but much less for EX-5. Ag-rich areas (Fig. 4) tended to correspond to S-rich areas (Fig. 3).

On element Pd EPMA photomicrographs (Fig. 5), large-scale segregation of $\mathrm{Pd}$ was found for PALA, EX-1, EX-2, EX-3, and EX-4, but less for EX-5. Pdrich areas (Fig. 5) tended to coincide with Ag-poor areas (Fig. 4) and S-poor areas (Fig. 3).
On element $\mathrm{Cu}$ EPMA photomicrographs (Fig. 6 ), large-scale segregation of $\mathrm{Cu}$ was likewise seen for PALA, EX-1, EX-2, EX-3, and EX-4, but less for EX-5. Cu-rich areas (Fig. 6) tended to coincide with Pd-rich areas (Fig. 5).

On element Zn EPMA photomicrographs (Fig. 7), large-scale segregation of $\mathrm{Zn}$ was confirmed for EX1, EX-2, EX-3, and EX-4, but small-scale for PALA

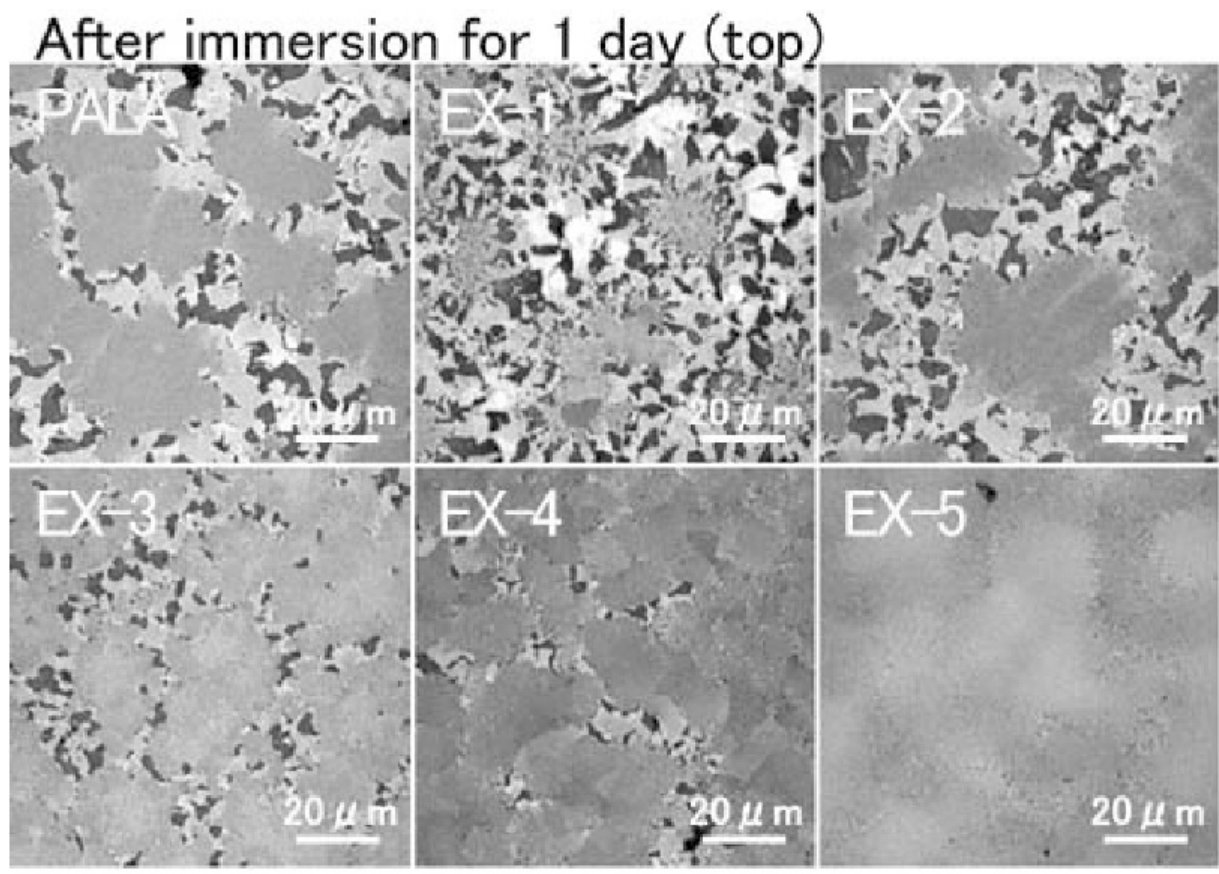

\section{After immersion for 7 days (bottom)}

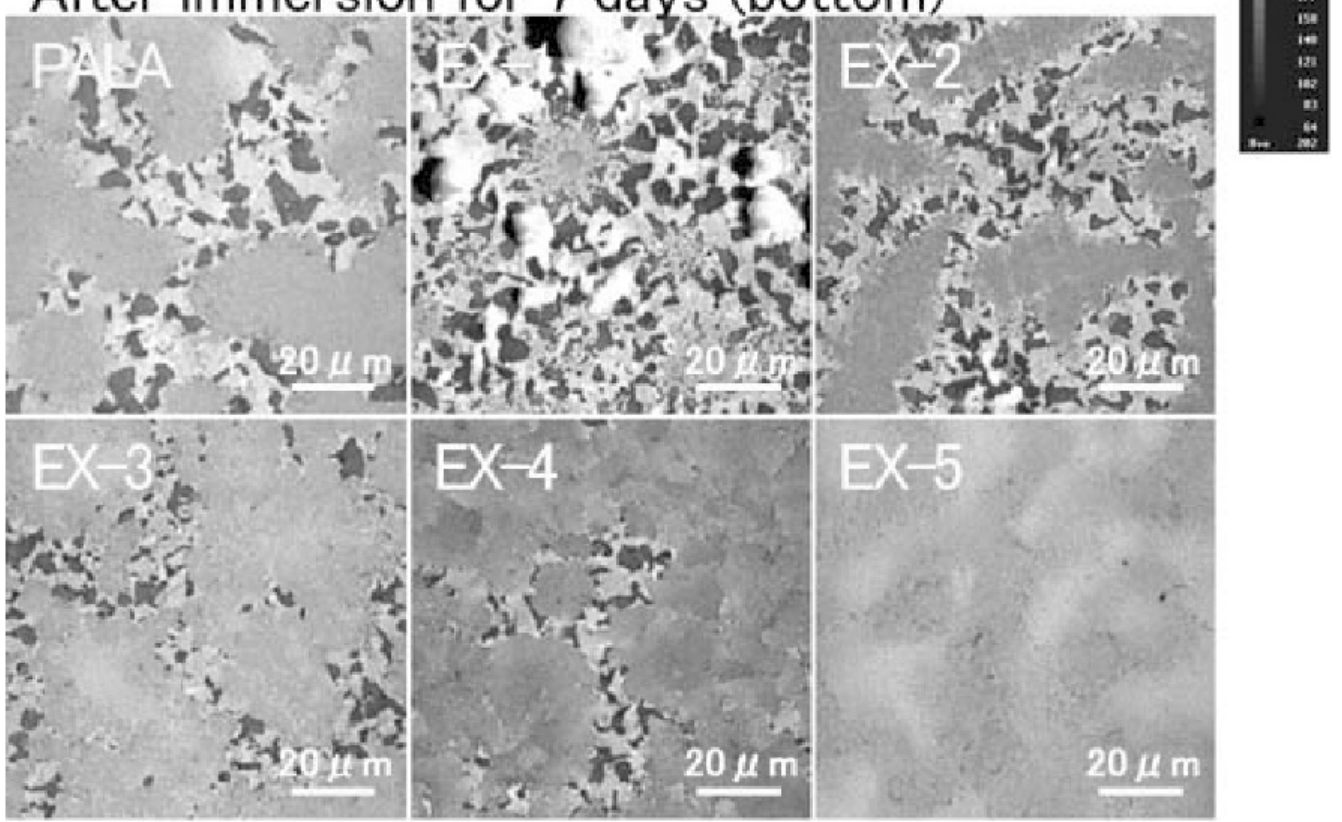

Fig. 4 Element Ag EPMA photomicrographs of cast control Ag-20Pd-12Au-20Cu alloy and five experimental Ag-low Pd-Au-Cu alloys immersed in $0.1 \% \mathrm{Na}_{2} \mathrm{~S}$ for 1 day (top) and 7 days (bottom) 
and EX-5. The $\mathrm{Zn}$ distributions resembled those of $\mathrm{Pd}$.

On element $\mathrm{Au}$ EPMA photomicrographs (Fig. 8), only a slight segregation of $\mathrm{Au}$ was found for EX-1. In other words, $\mathrm{Au}$ seemed to distribute homogeneously for the other alloys. Black regions on EX-1 (Figs. 5-8) superimposed on S-rich areas (Fig. $3)$.
Fig. 9 shows the CP and EPMA color photomicrographs of elements $\mathrm{S}, \mathrm{Ag}, \mathrm{Pd}, \mathrm{Cu}, \mathrm{Zn}$, and $\mathrm{Au}$ of cast one experimental Ag-low $\mathrm{Pd}-\mathrm{Au}-\mathrm{Cu}$ alloy (EX-1) after immersion in $0.1 \% \mathrm{Na}_{2} \mathrm{~S}$ for seven days. With color EPMA, red color depicts presence of high concentration of an element, whilst low concentration and absence of an element are represented by blue and black colors. It was re-confirmed that
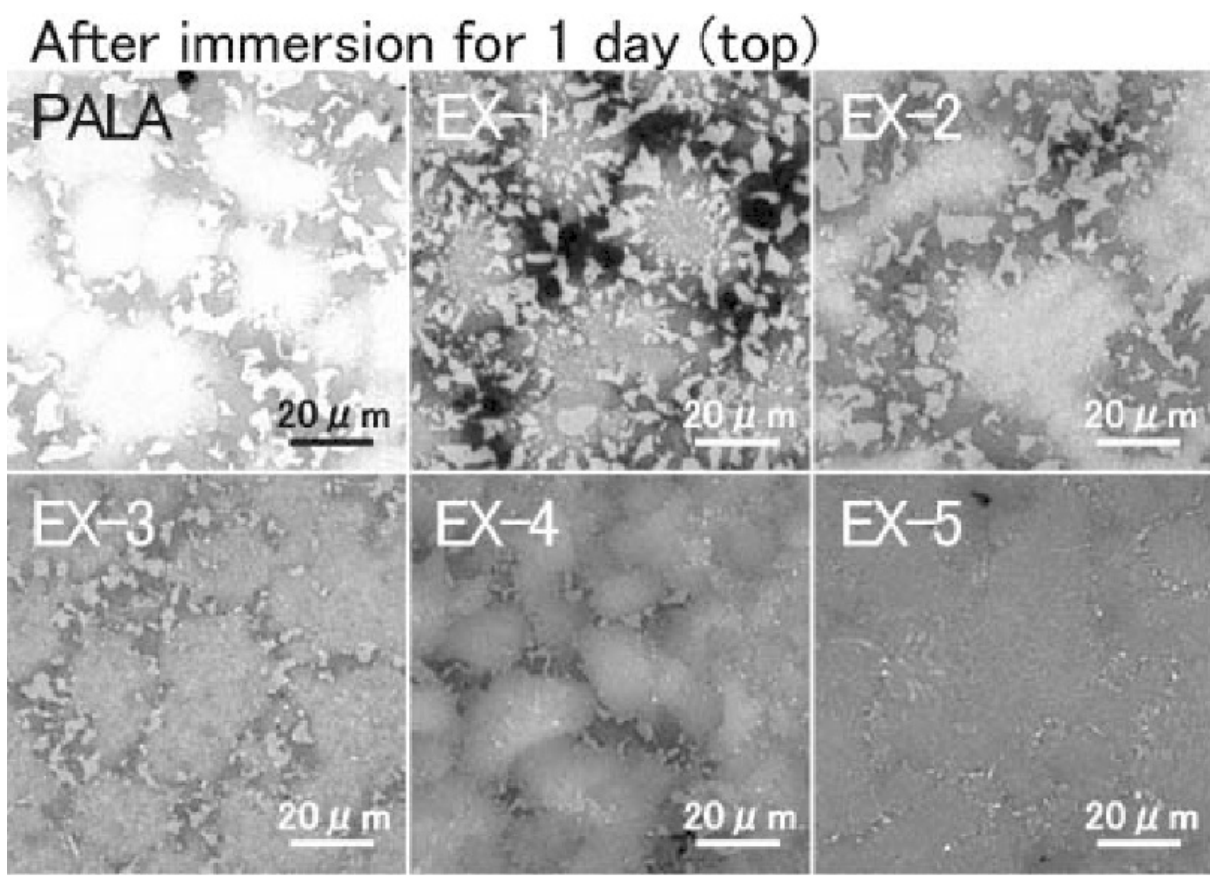

\section{After immersion for 7 days (bottom)}

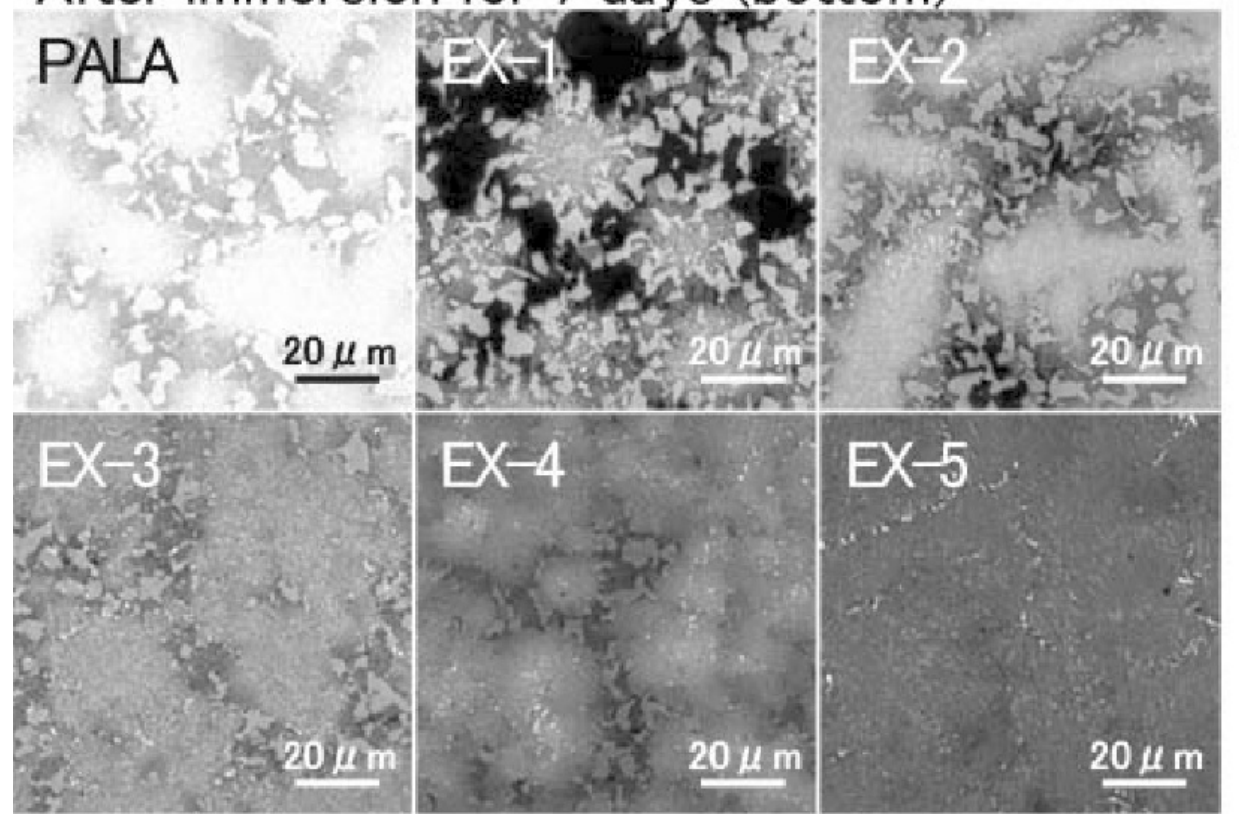

Fig. 5 Element Pd EPMA photomicrographs of cast control $\mathrm{Ag}-20 \mathrm{Pd}-12 \mathrm{Au}-20 \mathrm{Cu}$ alloy and five experimental Ag-low $\mathrm{Pd}-\mathrm{Au}-\mathrm{Cu}$ alloys immersed in $0.1 \% \mathrm{Na}_{2} \mathrm{~S}$ for 1 day (top) and 7 days (bottom). 
sulfuration preferentially occurred on Ag-rich $\mathrm{Pd}$ poor (virtually Pd-deficient) areas, which appeared black on CP (BSE image). Pd-rich Ag-poor zones, which appeared white on $\mathrm{CP}$, had little coupling with sulfur. The distributions of $\mathrm{Cu}$ and $\mathrm{Zn}$ were similar to that of $\mathrm{Pd}$, whereas $\mathrm{Au}$ appeared to distribute uniformly except the regions where sulfide precipitated.
TF-XRD analyses before and after immersion in 0.1\% $\mathrm{Na} \mathrm{S}_{2} \mathrm{~S}$ solution

Figs. 10(a) to 10(c) show the TF-XRD patterns of control $\mathrm{Ag}-20 \mathrm{Pd}-12 \mathrm{Au}-20 \mathrm{Cu}$ alloy and five experimental Ag-low $\mathrm{Pd}-\mathrm{Au}-\mathrm{Cu}$ alloys before immersion in $0.1 \% \mathrm{Na}_{2} \mathrm{~S}$, after immersion in $\mathrm{Na}_{2} \mathrm{~S}$ for one day, and after immersion in $\mathrm{Na}_{2} \mathrm{~S}$ for seven days respectively. Fig. 10(d) then shows the peak labeling of the crys-

After immersion for 1 day (top)

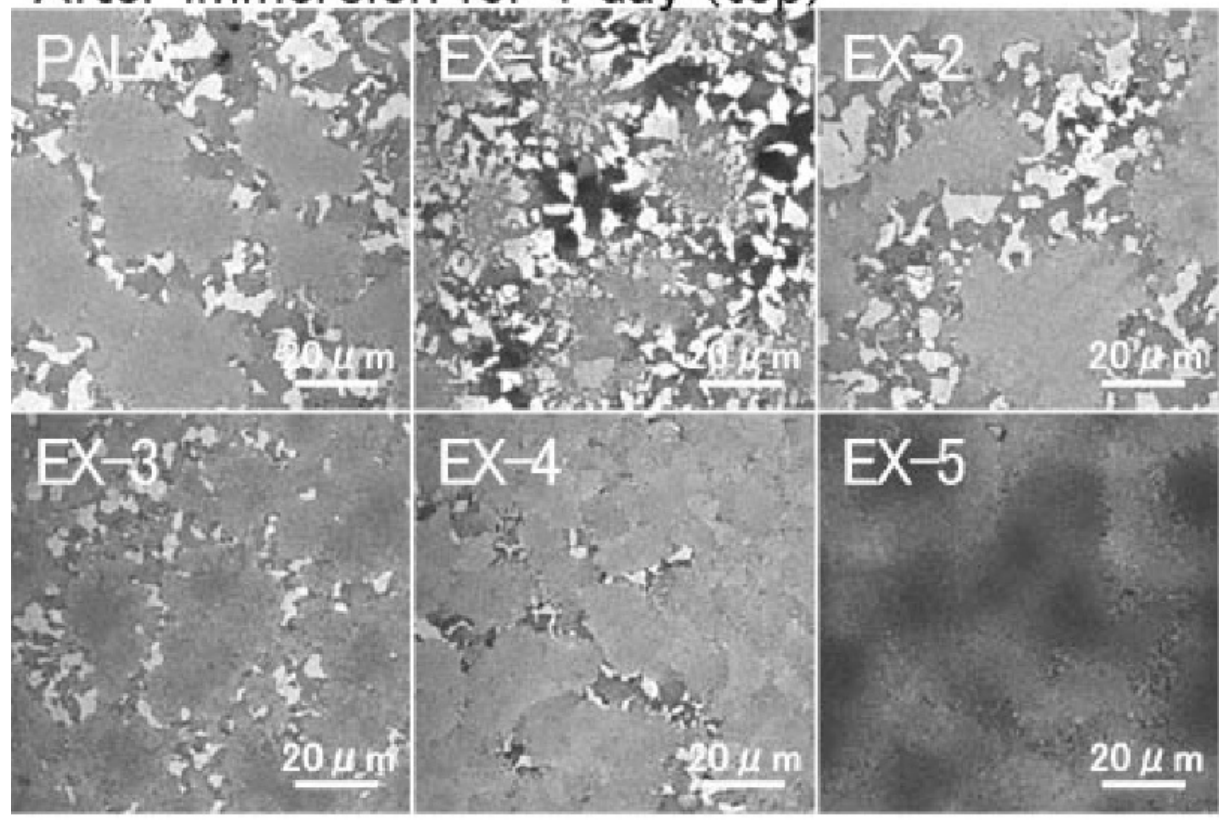

$\mathrm{Cu}$

After immersion for 7 days (bottom)
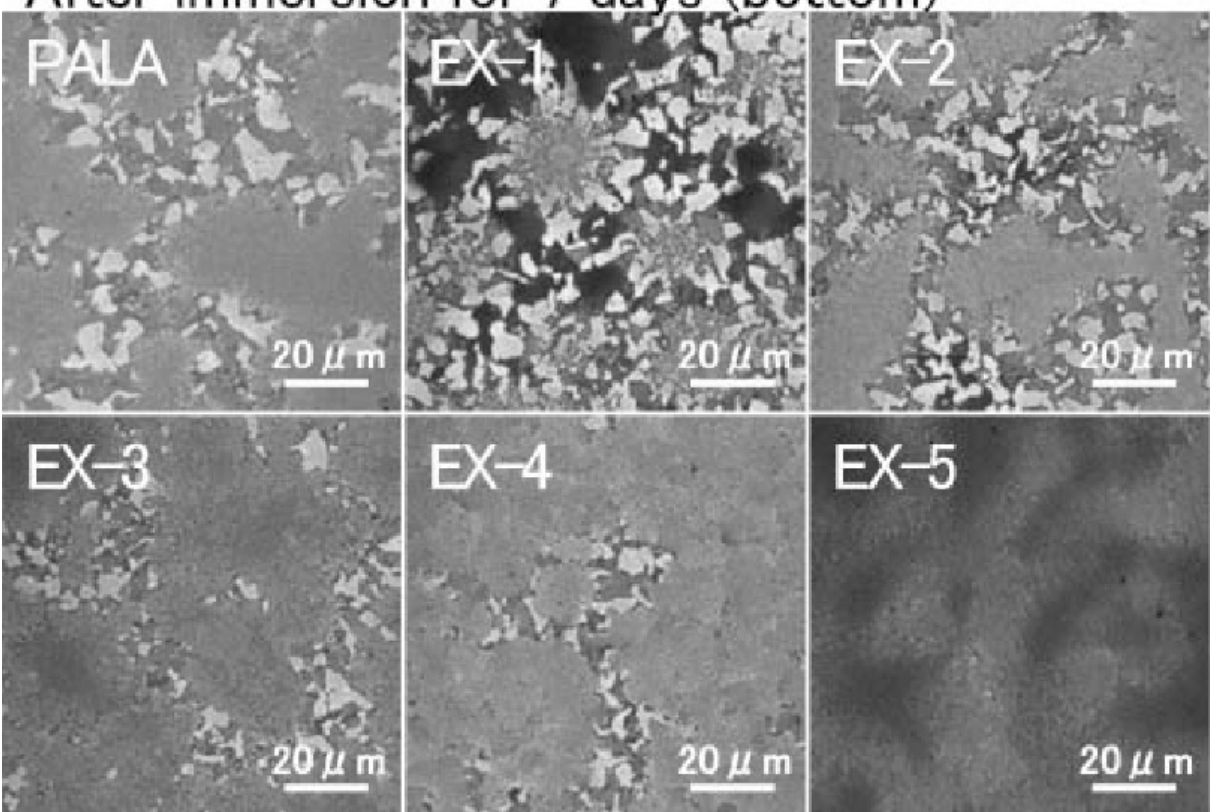

Fig. 6 Element $\mathrm{Cu}$ EPMA photomicrographs of cast control Ag-20Pd-12Au-20Cu alloy and five experimental Ag-low Pd-Au-Cu alloys immersed in $0.1 \% \mathrm{Na}_{2} \mathrm{~S}$ for 1 day (top) and 7 days (bottom). 
tals formed on one experimental Ag-low $\mathrm{Pd}-\mathrm{Au}-\mathrm{Cu}$ alloy (EX-1) which was dipped in $\mathrm{Na}_{2} \mathrm{~S}$ for seven days.

Before immersion, all the six alloys studied possessed five similar peaks and shoulders in the $2 \theta$ angle region between $38^{\circ}$ and $48^{\circ}$, indicating that all the alloys were basically made up of similar Agbased metallic phases (Fig. 10(a)).
Immersion in $\mathrm{Na}_{2} \mathrm{~S}$ for one day did not produce any detectable S-related XRD peaks on all the six alloys' surfaces (Fig. 10(b)). As a result, the peaks were analogous to those before immersion (Fig. $10(\mathrm{a}))$.

On the other hand, immersion in $\mathrm{Na}_{2} \mathrm{~S}$ for seven days caused noticeable S-related peaks (16 dotted lines) in addition to the five original alloy (M) peaks

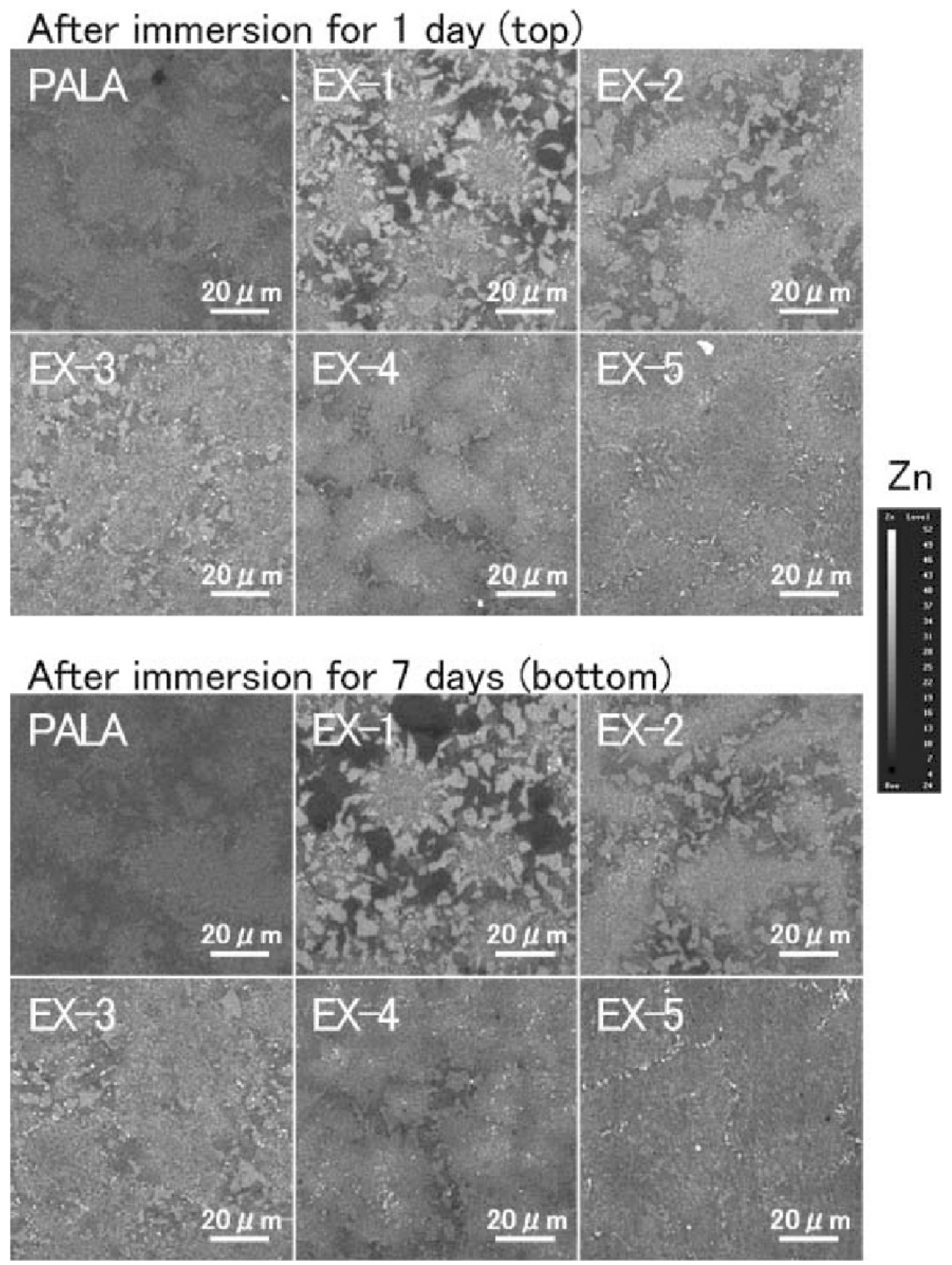

Fig. 7 Element Zn EPMA photomicrographs of cast control Ag-20Pd-12Au-20Cu alloy and five experimental Ag-low $\mathrm{Pd}-\mathrm{Au}-\mathrm{Cu}$ alloys immersed in $0.1 \% \mathrm{Na}_{2} \mathrm{~S}$ for 1 day (top) and 7 days (bottom). 
(five solid lines) (Fig. 10(c)). These new peaks appeared on identical $2 \theta$ angles for all the six alloys examined, but the peak heights differed among the six alloys. EX-1 had the strongest intensity for the new peaks, followed by EX-2, PALA, EX-3, and EX-4 in this order, whilst EX-5 had the weakest intensity.

On EX-1 which was immersed in $\mathrm{Na}_{2} \mathrm{~S}$ for seven days, a detailed XRD peak labeling was performed
(Fig. 10 (d)). Besides five original metal (M) peaks, 16 characteristic peaks were identified as those of three metal sulfides $-\mathrm{Ag}_{2} \mathrm{~S}, \mathrm{Cu}_{2} \mathrm{~S}$, and $\mathrm{PdS}$. The peaks of $\mathrm{Ag}_{2} \mathrm{~S}$ were predominant while those of $\mathrm{Cu}_{2} \mathrm{~S}$ and $\mathrm{PdS}$ were very small, suggesting that $\mathrm{Ag}_{2} \mathrm{~S}$ was a dominant metal sulfide which precipitated on all the six Ag-based alloys after immersion in $\mathrm{Na}_{2} \mathrm{~S}$ for seven days.

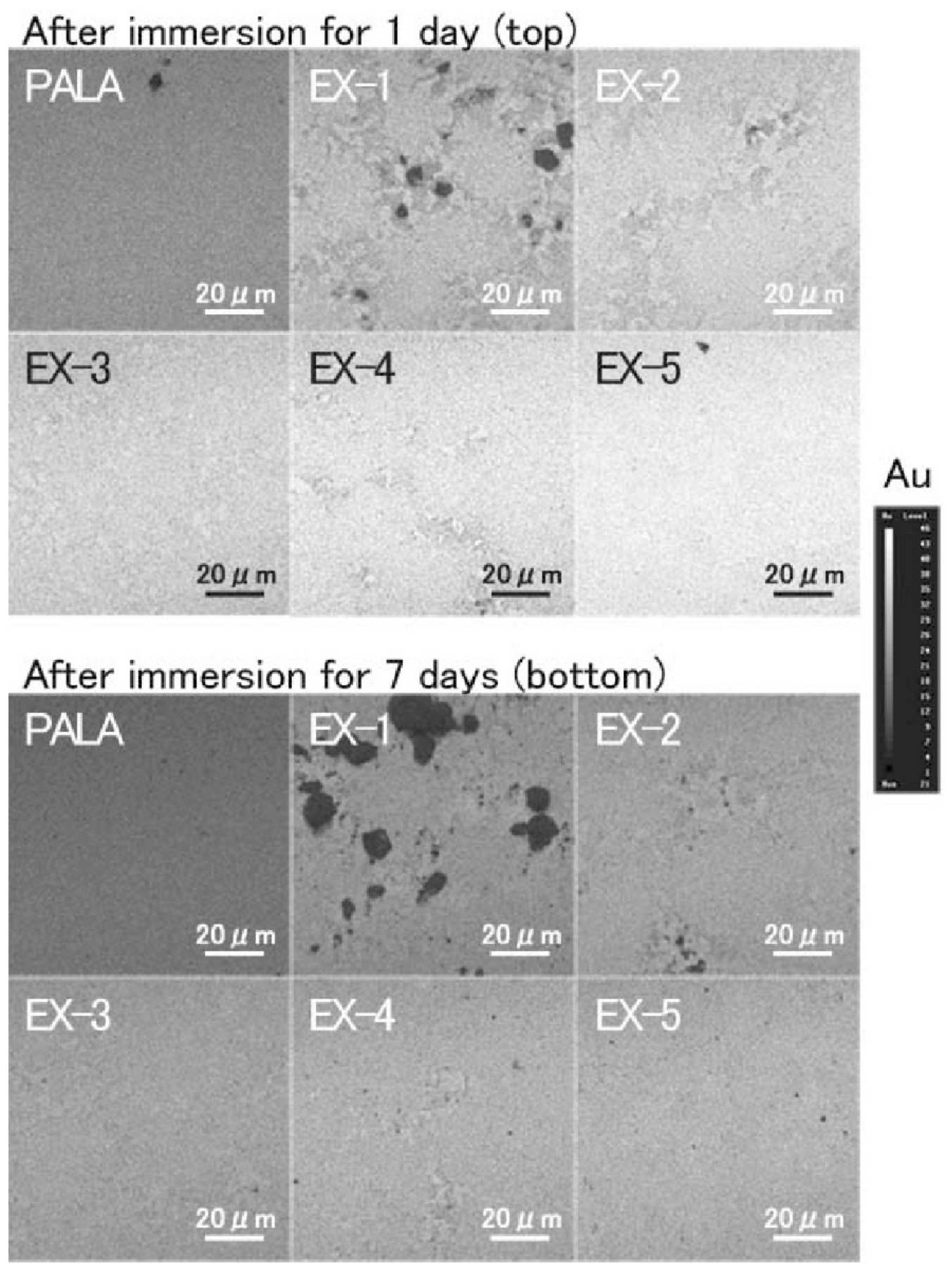

Fig. 8 Element $\mathrm{Au}$ EPMA photomicrographs of cast control $\mathrm{Ag}-20 \mathrm{Pd}-12 \mathrm{Au}-20 \mathrm{Cu}$ alloy and five experimental $\mathrm{Ag}$-low $\mathrm{Pd}-\mathrm{Au}-\mathrm{Cu}$ alloys immersed in $0.1 \% \mathrm{Na}_{2} \mathrm{~S}$ for 1 day (top) and 7 days (bottom). 

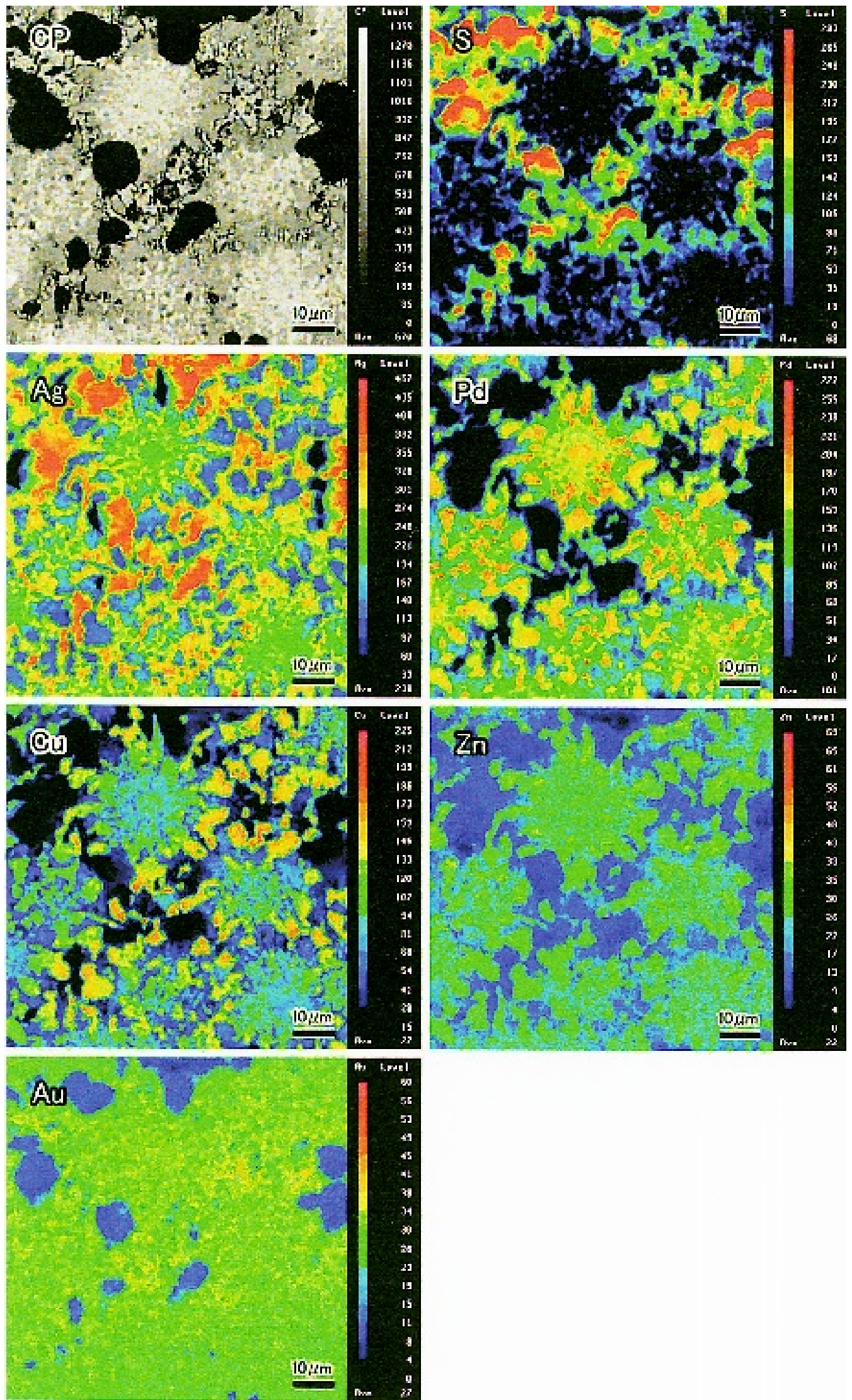

Fig. $9 \mathrm{CP}$ (composition image) and EPMA color photomicrographs of elements $\mathrm{S}, \mathrm{Ag}, \mathrm{Pd}, \mathrm{Cu}$, $\mathrm{Zn}$, and $\mathrm{Au}$ of cast one experimental Ag-low $\mathrm{Pd}-\mathrm{Au}-\mathrm{Cu}$ alloy (EX-1) after immersion in $0.1 \% \mathrm{Na}_{2} \mathrm{~S}$ for 7 days. 

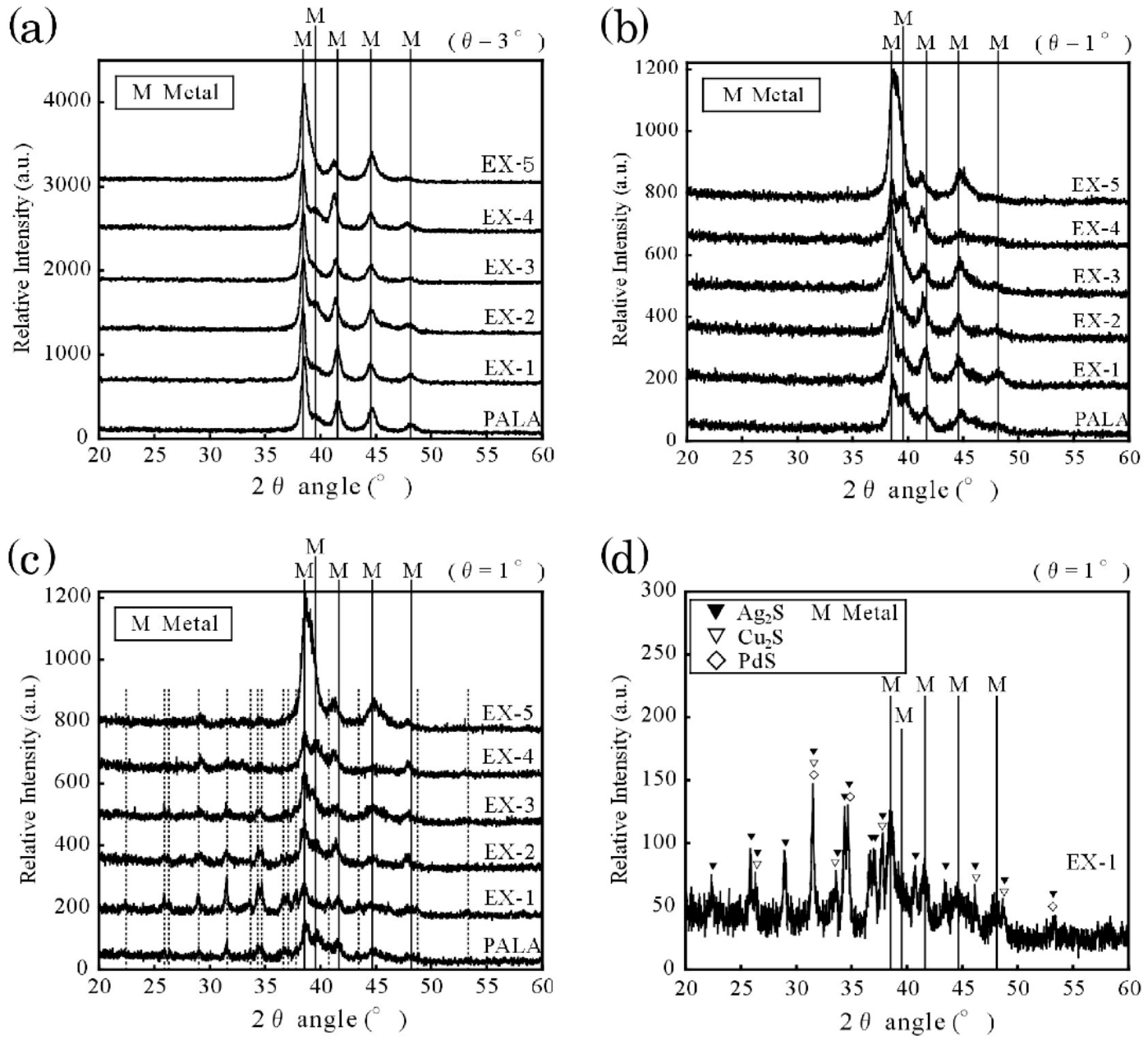

Fig. 10 TF-XRD patterns of cast control Ag-20Pd-12Au-20Cu alloy and five experimental Ag-low Pd-Au-Cu alloys: (a) before immersion in $0.1 \% \mathrm{Na}_{2} \mathrm{~S}$; (b) after immersion in $0.1 \% \mathrm{Na}_{2} \mathrm{~S}$ for 1 day; (c) after immersion in $0.1 \% \mathrm{Na}_{2} \mathrm{~S}$ for 7 days; and (d) peak labeling of the crystals formed on EX-1 which was dipped in $0.1 \% \mathrm{Na}_{2} \mathrm{~S}$ for 7 days.

$X P S$ analyses after immersion in $0.1 \% \mathrm{Na}_{2} \mathrm{~S}$ solution Fig. 11 shows the XPS wide scan spectra of the uppermost layer of cast control Ag-20Pd-12Au-20Cu alloy and five experimental $\mathrm{Ag}$-low $\mathrm{Pd}-\mathrm{Au}-\mathrm{Cu}$ alloys after immersion in $0.1 \% \mathrm{Na}_{2} \mathrm{~S}$ for one day. It became clear that $\mathrm{S}$ peaks (S 2p and S 2s) (labeled by two big arrows) were superimposed onto the peaks of original cast and polished alloy surfaces, such as those of $\mathrm{Cu} 2 \mathrm{p}, \mathrm{Ag} 3 \mathrm{~d}, \mathrm{Pd} 3 \mathrm{~d}$, and $\mathrm{Au}$ 4f, etc., suggesting that sulfuration - which was detected by XPS - actually occurred on all the alloys after immersion in $0.1 \% \mathrm{Na}_{2} \mathrm{~S}$ for only one day. Besides $\mathrm{Cu}$, $\mathrm{Ag}, \mathrm{Pd}$, and Au elements, O KLL was also found present as oxides and $\mathrm{C} 1 \mathrm{~s}$ as contaminated hydrocarbon.

Fig. 12 shows the XPS narrow scan spectra of the uppermost layer of cast control Ag-20Pd-12Au$20 \mathrm{Cu}$ alloy and five experimental Ag-low $\mathrm{Pd}-\mathrm{Au}-\mathrm{Cu}$ alloys after immersion in $0.1 \% \mathrm{Na}_{2} \mathrm{~S}$ for one day. There were no remarkable differences in characteristic spectra shapes among the six Ag-based alloys,

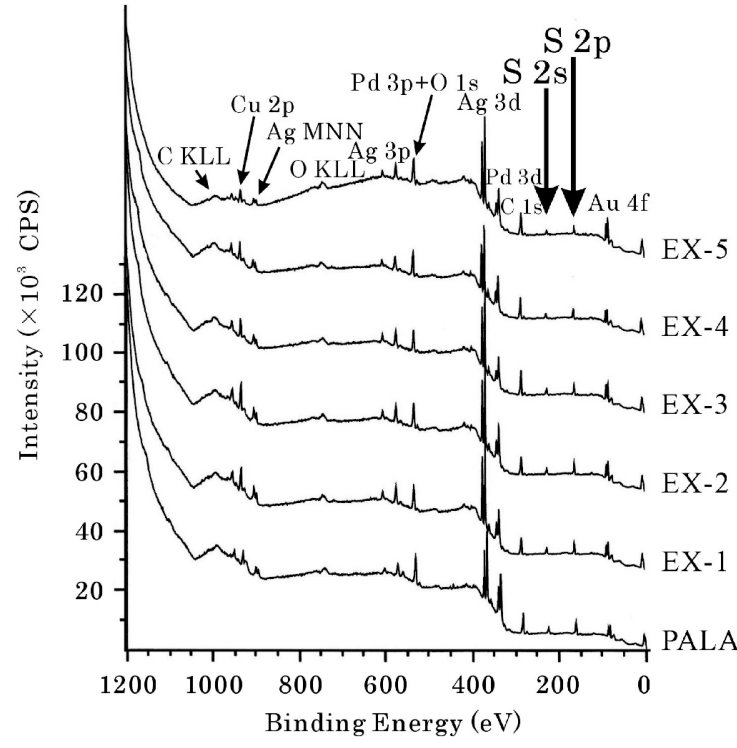

Fig. 11 XPS wide scan spectra of the uppermost layer of cast control $\mathrm{Ag}-20 \mathrm{Pd}-12 \mathrm{Au}-20 \mathrm{Cu}$ alloy and five experimental $\mathrm{Ag}$-low $\mathrm{Pd}-\mathrm{Au}-\mathrm{Cu}$ alloys after immersion in $0.1 \% \mathrm{Na}_{2} \mathrm{~S}$ for 1 day. 

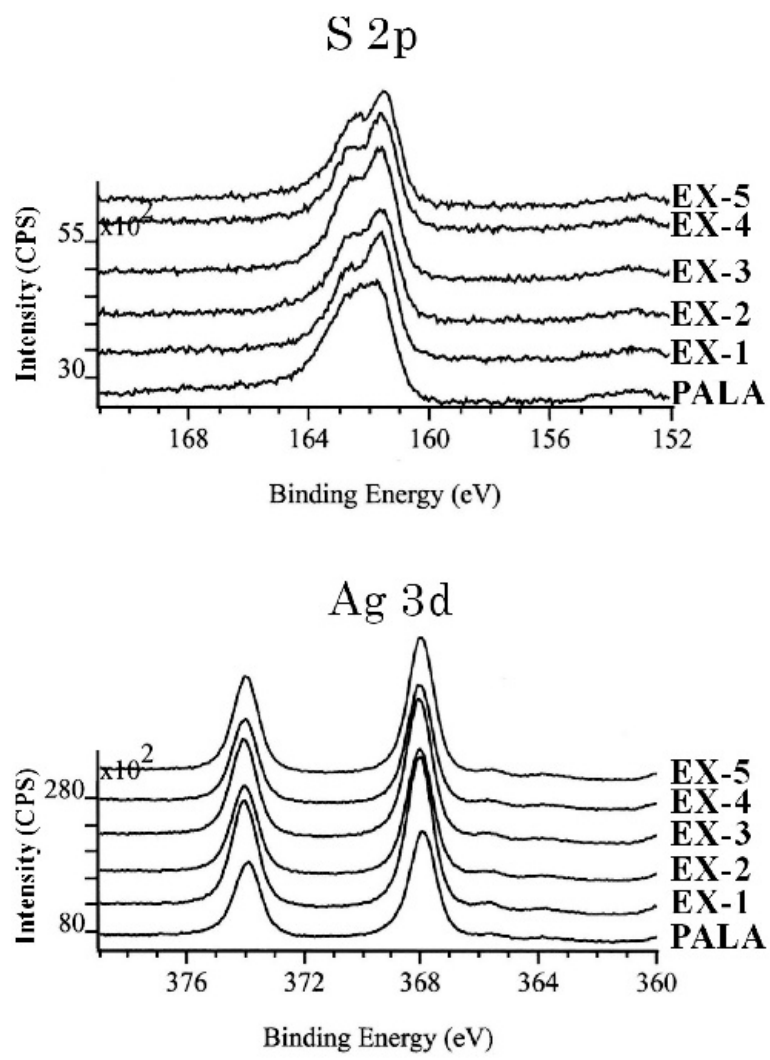

$\operatorname{Pd} 3 d$
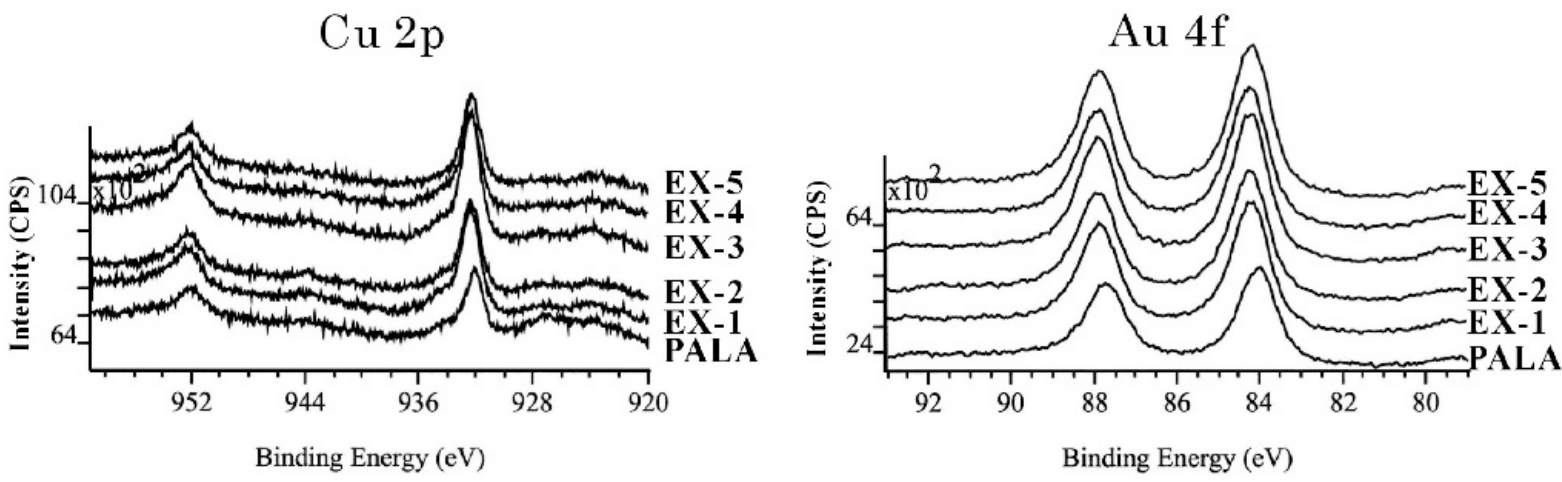

Fig. 12 XPS narrow scan spectra of the uppermost layer of cast control Ag-20Pd-12Au-20Cu alloy and five experimental Ag-low $\mathrm{Pd}-\mathrm{Au}-\mathrm{Cu}$ alloys after immersion in $0.1 \% \mathrm{Na}_{2} \mathrm{~S}$ for 1 day, whereby the spectra corresponded to the five elements of $\mathrm{S}, \mathrm{Ag}, \mathrm{Pd}, \mathrm{Cu}$, and $\mathrm{Au}$.

whereby the spectra corresponded to the five elements of $\mathrm{S}, \mathrm{Ag}, \mathrm{Pd}, \mathrm{Cu}$, and Au. This finding implied that sulfides formed on all the six alloy surfaces - after dipping in $0.1 \% \mathrm{Na}_{2} \mathrm{~S}$ solution for only one day - were basically identical.

\section{DISCUSSION}

By SEM/EDX, we observed significant phase segregation $^{22,23)}$ in five alloys (PALA, EX-1, EX-2, EX-3, and EX-4) out of six alloys after casting (Fig. 1). The reason for this segregation phenomenon is un- clear, but alloy melting and slow cooling during casting might produce such segregations ${ }^{23)}$. Phase segregations are undesirable for sulfuration resistance, because sulfuration-vulnerable Ag-rich Pd-poor phases are produced ${ }^{5)}$. One alloy (EX-5) was least phase-segregated, and had two phases consisting of relatively analogous chemical compositions of $\mathrm{Ag}, \mathrm{Pd}$, $\mathrm{Cu}, \mathrm{Zn}$, and $\mathrm{Au}$ (Fig. 1), which seemed to be advantageous in terms of sulfuration resistance.

We employed three different techniques to evaluate the sulfuration of Ag-based alloys. Approximate detection depths of SEM/EPMA, TF-XRD, and XPS 
were $100 \mathrm{~nm}, 500 \mathrm{~nm}$, and $5 \mathrm{~nm}$ respectively. Therefore, with SEM/EPMA and XPS, we could trace the sulfides formed on the examined alloys after immersion in $0.1 \% \mathrm{Na}_{2} \mathrm{~S}$ for one short day, but not so with TF-XRD. After immersion for seven days, the enlarged sulfides could be identified by both SEM/ EPMA and TF-XRD. In the evaluation of the sulfuration resistance of six Ag-based alloys, alloy surfaces immersed in $0.1 \% \mathrm{Na}_{2} \mathrm{~S}$ for one and seven days were regarded as standard and accelerated conditions respectively.

It was judged from SEM/EPMA (Figs. 2-9) and TF-XRD (Fig. 10) analyses that all Ag-based alloys were sulfurated in Ag-rich Pd-poor areas. Degree of sulfuration and reaction kinetics, however, varied depending on the alloy type. The six Ag-based alloys examined could be classified into two groups: Group 1 - fast and intensely sulfurated group - to which EX-1, EX-2, EX-3, and EX-4 belonged; Group $2-$ slow and slightly sulfurated group - to which PALA and EX-5 belonged. The sulfides identified were mostly $\mathrm{Ag}_{2} \mathrm{~S}$, while $\mathrm{PdS}$ and $\mathrm{Cu}_{2} \mathrm{~S}$ were found in smaller quantities (Fig. 10(d)). Considering that $\mathrm{Cu}$ and $\mathrm{Zn}$ distributions were similar to that of $\mathrm{Pd}$, and that $\mathrm{Au}$ distributed homogeneously, the growing sulfuration of all the six Ag-based alloys examined might occur predominantly between $\mathrm{Ag}$ and $\mathrm{S}$ in $\mathrm{Ag}$ rich $\mathrm{Pd}$-poor, $\mathrm{Cu}$-poor, and $\mathrm{Zn}$-poor phases. However, it should be noted that for all the six Ag-based alloys dipped in $0.1 \% \mathrm{Na}_{2} \mathrm{~S}$ for only one day, their XPS peak heights of $\mathrm{S} 2 \mathrm{p}$ were similar (Figs. 11 and 12). This finding might serve to support the hypothesis that upon exposure to $0.1 \% \mathrm{Na}_{2} \mathrm{~S}$ solution, the entire uppermost surface of Ag-based alloys was instantaneously covered by an ultra-thin sulfur tarnish layer (around $10 \mathrm{~nm}$ ) presumably made up of $\mathrm{Ag}_{2} \mathrm{~S}$ and $\mathrm{PdS}^{5)}$. If the alloy is not resistant to further sulfuration, silver sulfide $\left(\mathrm{Ag}_{2} \mathrm{~S}\right)$ might grow rapidly and predominantly in Ag-rich $\mathrm{Pd}$-poor phases to the extent whereby TF-XRD can detect with a large diffraction peak ${ }^{5}$. On the contrary, if the alloy is resistant to further sulfuration, the sulfide layer might grow very slowly such that only a weak intensity for $\mathrm{Ag}_{2} \mathrm{~S}$ peak was registered.

In addition to analyses by SEM/EPMA, TF$\mathrm{XRD}$, and XPS, an attempt is made here to compare the sulfuration resistance of the six Ag-based alloys based on their compositions (Table 1). There is a general understanding that $\mathrm{Pd}$ and $\mathrm{Au}$ strongly and moderately retard the sulfuration of $\mathrm{Ag}^{24,25)}$, respectively. On the other hand, $\mathrm{Cu}$ moderately accelerates sulfuration $^{26)}$. Based on these notions, EX-1 (8\% less $\mathrm{Pd}$ and $8 \%$ more $\mathrm{Au}$ than PALA) was most susceptible to sulfuration, implying that a mere simple substitution of $\mathrm{Pd}$ with $\mathrm{Au}$ could not maintain the sulfuration resistance of control PALA. Likewise, $\mathrm{EX}-2, \mathrm{EX}-3$, and EX-4 - which had 0 to $8 \%$ less $\mathrm{Ag}$, 8 to $10 \%$ less $\mathrm{Pd}, 12$ to $18 \%$ more $\mathrm{Au}$, and 0 to $4 \%$ less $\mathrm{Cu}$ than PALA - could not maintain the sulfuration resistance of control PALA. Only EX-5 which had $10 \%$ less $\mathrm{Pd}, 18 \%$ more $\mathrm{Au}$, and $8 \%$ less $\mathrm{Cu}$ than PALA - possessed a sulfuration resistance equal or superior to that of control PALA. We believed that the excellent sulfuration resistance of EX5 could be attributed to two factors: (i) increase of $\mathrm{Au}$ by $18 \%$ and decrease of $\mathrm{Cu}$ by $8 \%$, while reducing $\mathrm{Pd}$ content by $10 \%$; and (ii) phase segregation of a smaller scale as mentioned above.

At this juncture, we have completed the evaluation of the sulfuration resistance of five experimental Ag-(10 to $12 \%) \mathrm{Pd}-\mathrm{Au}-\mathrm{Cu}$ alloys. However, it also seems to be necessary to carry out further studies that entail castability tests ${ }^{27,28)}$, mechanical strength tests ${ }^{29,30)}$, and biocompatibility tests ${ }^{31-33)}$ in order to thoroughly clarify the practical usefulness of our newly developed EX-5 (46Ag-10Pd-30Au-12Cu alloy). If confirmed to be a viable substitute for PALA, EX5 would be a useful casting alloy in future dental clinics when the Pd price surges again.

\section{CONCLUSIONS}

In the present study, five experimental Ag-low $\mathrm{Pd}(10$ to $12 \%)-\mathrm{Au}-\mathrm{Cu}$ alloys were prepared in a bid to substitute a commercial Ag-based alloy (46Ag-20Pd$12 \mathrm{Au}-20 \mathrm{Cu}$ alloy) (control). To this end, cast specimens were made, metallography was examined, and their sulfuration resistance was evaluated by SEM/ EPMA, TF-XRD, and XFS after immersion in $0.1 \%$ $\mathrm{Na}_{2} \mathrm{~S}$ solution. All alloys were phase-segregated, and sulfuration occurred predominantly in Ag-rich $\mathrm{Pd}$ poor phases with different degrees, depending on the alloy type. In particular, one experimental alloy (46Ag-10Pd-30Au-12Cu alloy) possessed a sulfuration resistance equal or superior to that of the commercial Ag-based alloy, which could be due to the following factors:

(i) In terms of composition, the experimental Ag-low $\mathrm{Pd}-\mathrm{Au}-\mathrm{Cu}$ alloy had a $\mathrm{Pd}$ content $10 \%$ less than that of the commercial $46 \mathrm{Ag}-20 \mathrm{Pd}-12 \mathrm{Au}-20 \mathrm{Cu}$ alloy. However, its content of $\mathrm{Au}$ - a moderate sulfuration retarder - was $18 \%$ more than the control alloy, while its content of $\mathrm{Cu}-$ a moderate sulfuration accelerator - was 8\% less than the control alloy. Taken together, this composition enabled the experimental alloy to possess excellent sulfuration resistance;

(ii) In terms of phase segregation, it was a small-scale one for the experimental alloy as the compositions of Ag-rich $\mathrm{Pd}$-poor phase and Ag-poor Pd-rich phase were relatively analogous. Further, the Ag-rich Pd-poor phase was still sulfurationresistant.

If proven to be a viable alternative to the commercial $46 \mathrm{Ag}-20 \mathrm{Pd}-12 \mathrm{Au}-20 \mathrm{Cu}$ alloy, this newly developed $46 \mathrm{Ag}-10 \mathrm{Pd}-30 \mathrm{Au}-12 \mathrm{Cu}$ alloy is a potential cast- 
ing alloy candidate in future dental clinics when the price of $\mathrm{Pd}$ surges again.

\section{ACKNOWLEDGEMENTS}

This research was supported in part by a Grant-inaid for High-Tech Research Project (2005-2009), as well as by Grants-in-aid for Scientific Research (Nos. 14571858 and 17592037) from the Ministry of Education, Culture, Sports, Science and Technology, Japan.

\section{REFERENCES}

1) The Committee on Evaluation and Status Reports of Dental Materials and Devices. A review and the future in dental casting Au-Ag-Pd alloys. Part 1: Literature survey and alternatives to dental Au-Ag-Pd alloys. J J Dent Mater 2003; 22: 531-563.

2) The Committee on Evaluation and Status Reports of Dental Materials and Devices. A review and the future in dental casting Au-Ag-Pd alloys. Part 2: The basic properties database of Au-Ag-Pd-Cu alloys. J J Dent Mater 2003; 22: 564-598.

3) Okazaki K. Studies on Au-Ag-Pd-Cu alloys. Part 1: Effects of $\mathrm{Au}$ component on some properties of alloys. J Japan Soc Dent Appar Mat 1979; 20: 233-239.

4) Niemi L, Holland RI. Tarnish and corrosion of a commercial dental Ag-Pd-Cu-Au casting alloy. J Dent Res 1984; 63: 1014-1018.

5) Endo K, Ohno H. Microstructure and anodic polarization behavior of experimental $\mathrm{Ag}-18 \mathrm{Cu}-15 \mathrm{Pd}-12 \mathrm{Au}$ alloy in aqueous sulfide solution. J Mater Sci 2003; 14: 427-434.

6) Endo K, Araki Y, Kawashima I, Yamane Y, Ohno H, Matsuda K. In vitro study on the corrosion behavior of three commercial Ag-Pd-Cu-Au alloys in Ringer's and $0.1 \% \mathrm{Na}_{2} \mathrm{~S}$ solutions. Higashi Nippon Shigaku Zassi 1989; 8: 155-163.

7) Yoshida T, Miyasaka T, Okamura H, Oka K, Yamazaki E, Naruse S, Asaki T, Doi Y. Properties of low karat gold alloys. Part 1: Mechanical properties of the alloys containing 5 mass\% Pd. J J Dent Mater 2002; 21: 285-293.

8) Matsumoto M, Hattori M, Hasegawa K, Yoshinari M, Kawada E, Oda Y, Mamada K, Yoshida T. Property of low karat gold alloys. Part 2: Corrosion resistance and tarnish of the alloys containing 5 mass\% Pd. J J Dent Mater 2002; 21: 302-307.

9) Lang BR, Bernier SH, Giday Z, Asgar K. Tarnish and corrosion of noble metal alloys. J Prosthet Dent 1982; 48: 245-252.

10) Tsuruta S. Tarnish and corrosion of silver alloys in $\mathrm{Na}_{2} \mathrm{~S}$ solution. Aichi-Gakuin Dent Sci 1993; 31: 243-259.

11) Mueller HJ, Lenke JW, Bopna MS. Surface analysis of tarnished dental alloys. Scanning Microsc 1988; 2: 777787.

12) Yamatoya F, Nakamura K, Goto S. Effects of gold addition for the properties of casting $\mathrm{Pd}-\mathrm{Cu}-\mathrm{Ag}$ alloy. J J Dent Mater 1985; 4: 730-753.

13) Koyama K. Tarnish/corrosion and microstructure of silver-base and copper-base casting alloys. AichiGakuin Dent Sci 1996; 34: 481-498.

14) Takada Y, Okuno O. Effect of heat history on the corrosion of ferritic stainless steels used for dental magnetic attachments. Dent Mater J 2005; 24: 391-397.

15) Tuccillo JJ, Nielsen JP. Microprobe analysis of an in vivo discoloration. J Prosthet Dent 1974; 31: 285-289.

16) Ochi M, Endo K, Ohno H, Takasusuki N, Matsubara $\mathrm{H}$, Maida T. In vitro corrosion of dental Ag-based alloys in polyvinylpyrrolidone iodine solution. Dent Mater J 2005; 24: 422-427.

17) Niemi L, Hero H. The structure of a commercial dental Ag-Pd-Cu-Au casting alloy. J Dent Res 1984; 63: 149154.

18) Endo K, Ohno H, Matsuda K, Asakura S. Electrochemical and surface studies on the passivity of a dental Pd-based casting alloy in alkaline sulphide solution. Corros Sci 2003; 45: 1491-1504.

19) Suoninen E, Hero H. Effect of palladium on sulfide tarnishing of noble metal alloys. J Biomed Mater Res 1985; 19: 917-934.

20) Wataha JC, Malcolm CT. Effect of alloy surface composition on release of elements from dental casting alloys. J Oral Rehabil 1996; 23: 583-589.

21) Niemi L, Minni E, Ivaska A. An electrochemical and multispectroscopic study of corrosion of $\mathrm{Ag}-\mathrm{Pd}-\mathrm{Cu}-\mathrm{Au}$ alloys. J Dent Res 1986; 65: 888-891.

22) Chen KI, Lin JH, Ju CP. Microstructure and segregation behavior of palladium in silver-copper-palladium alloys. J Dent Res 1996; 75: 1497-1502.

23) Drapal S, Pomajbik J. Segregation in precious-metal dental-casting alloys. J Dent Res 1993; 76: 587-591.

24) Vaidyanathan TK, Prasad A. In vitro corrosion and tarnish analysis of the Ag-Pd binary system. J Dent Res 1981; 60: 707-715.

25) Nakamura T, Nakamura K, Goto S. Effects of gold addition on the properties of casting $20 \mathrm{Pd}-5 \sim 20 \mathrm{Cu}-\mathrm{Ag}$ alloys. J J Dent Mater 1995; 14: 69-86.

26) Kifune T, Nakamura K, Goto S. Properties of the casting Ag-Pd-Cu alloys. J J Dent Mater 1987; 6: 768-787.

27) Watanabe I, Woldu M, Watanabe K, Okabe T. Effects of casting method on castability of titanium and dental alloys. J Mater Sci Mater Med 2000; 11: 547-553.

28) Wang TJ, Kobayashi E, Doi H, Yoneyama T. Castability of Ti-6Al-7Nb alloy for dental casting. J Med Dent Sci 1999; 46: 13-19.

29) Churnjitapilom P, Goto S, Ogura H. Effects of heat treatments and $\mathrm{Sn}, \mathrm{Ga}$ and In additives on mechanical properties of $35 \mathrm{Ag}-30 \mathrm{Pd}-20 \mathrm{Au}-15 \mathrm{Cu}$ alloy. Dent Mater J 2004; 23: 474-489.

30) Goto S, Nakai A, Miyagawa Y, Ogura H. Development of $\mathrm{Ag}-\mathrm{Pd}-\mathrm{Au}-\mathrm{Cu}$ alloys for multiple dental applications. Part 2: Mechanical properties of experimental Ag-Pd$\mathrm{Au}-\mathrm{Cu}$ alloys containing $\mathrm{Sn}$ or $\mathrm{Ga}$ for ceramic-metal restorations. Dent Mater J 2001; 21: 135-147.

31) Taira M, Sasaki M, Yamaura-Tanaka C, Saitoh S, Kimura S, Araki Y. Effects of $\mathrm{Ni}^{2+}$ ions on cell viability and NO production of murine peritoneal exudates cells (macrophages) with and without lipopolysaccharide stimulation. Dent Mater J 2005; 24: 
304-310.

32) Niemi L, Hensten-Pettersen A. In vitro cytotoxicity of Ag-Pd-Cu-based casting alloys. J Biomed Mater Res 1985; 19: 549-561.
33) Niemi L, Syrjanen S, Hensten-Pettersen A. The biocompatibility of a dental Ag-Pd-Cu-Au-based casting alloy and its structural components. J Biomed Mater Res 1985; 19: 535-548. 